\title{
KARAKTERISTIK SENI LUKIS KARYA SOEGENG TOEKIO
}

\author{
Satriana Didiek Isnanta \\ Fakultas Seni Rpa dan Desain ISI Surakarta \\ isnanta@gmail.com
}

\begin{abstract}
ABSTRAC
The study entitled "Characteristics Of Soegeng Toekio's Paintings". The focus of this research is to find the character of Soegeng Toekio's paintings in order to know the weaknesses and shortcomings Soegeng Toekio's works together. The first step taken is collecting data from all three sources of information required by the holistic art criticism, namely, the creation of works Soegeng Toekio's backgrounds as genetic information, Soegeng Toekio's paintings as objective information and gazerer comments as affective information. Once the source of the data collected and analyzed using analysis of interaction (the Information sources of genetic and affective) and interpretive analysis of sources of objective information. After all the data is analyzed and then synthesized and conclusions drawn with regard to the characteristics of Soegeng Toekio's painting.

Results from this study is the character of Soegeng Toekio's painting are illustrative figurative decorative style, the paintings with decorative styles, with strength in typical comical figure with forms like wayang beber. Illustrates the tradition of events identified from the human figure clothes which are then contrasted/ contrasted with popular contemporary colors.
\end{abstract}

Keywords: Soegeng Toekio, characteristics, painting, art criticism, holistic

\begin{abstract}
ABSTRAK
Penelitian berjudul "Karakteristik Seni Lukis Karya Soegeng Toekio". Fokus penelitian ini adalah mencari karakter seni lukis karya Soegeng Toekio dengan tujuan mengetahui kelemahan dan kekurangan karya Soegeng Toekio beserta karakter lukisannya. Langkah pertama yang dilakukan adalah pengumpulan data dari ketiga sumber informasi yang dipersyaratkan oleh kritik seni holistic yaitu, latar belakang penciptaan karya Soegeng Toekio sebagai informasi genetik, karya seni lukis Soegeng Toekio sebagai informasi obyektif dan tanggapan para penghayat sebagai informasi afektif. Setelah sumber data tersebut terkumpul kemudian dianalisis menggunakan interaksi analisis (sumber informasi genetik dan afektif) dan analisis interpretatif untuk sumber informasi obyektif. Setelah semua data dianalisis kemudian disintesakan dan ditarik kesimpulan yang berkaitan dengan karakteristik seni lukis karya Soegeng Toekio.

Hasil dari penelitian ini adalah karakter karya Soegeng Toekio bergaya dekoratif figuratif ilustratif, yaitu karya seni lukis dengan gaya dekoratif yang menggunakan cara penggambaran yang diindah-indahkan (stilasi), dengan kekuatan pada figur yang khas komikal dengan bentuk seperti wayang beber. Mengilustrasikan peristiwa tradisi yang diidentifikasi dari pakaian figur manusianya yang kemudian dikontraskan/ dipertentangkan dengan warna-warna popular kekinian.
\end{abstract}

Kata kunci: Soegeng Toekio, karakteristik, seni lukis, kritik seni, holistik. 


\section{PENDAHULUAN}

Setiap kelompok sosial (masyarakat) memiliki nilai yang diyakini esensi dan eksistensinya. Esensi dan eksistensi nilai itulah yang akhirnya membentuk simbolsimbol universial yang dapat diadop -si oleh individu termasuk seniman untuk berkomunikasi. Munculnya kemerdekaan berfikir dan perkembangan rasionalitas memunculkan perbedaan nilai yang dimiliki oleh setiap orang atau seniman, termasuk di dalamnya nilai-nilai seni. Pengembangan nilai seni individu itu diperoleh dari proses pendidikan, bukan tumbuh dalam pribadi setiap orang. Inilah mengapa nilai seni itu berakar dalam konteks sosio-budaya tertentu. (Sumardjo, 2000;187)

Soegeng Toekio lahir di Bandung pada tahun 1942, dibesarkan dalam budaya Jawa dan Sunda. Orang tuanya dari Jogja yang hijrah ke Bandung pada saat terjadi agresi militer Belanda ke dua. Saat Soegeng Toekio masih kecil sering diajak oleh ayahnya melihat ujicoba peluncuran roket di pantai Pangandaran. Selain sebagai seorang peneliti, ayah Soegeng Toekio mempunyai hobi membuat karya seni kaca (glass art) dan mempunyai ketertarikan kepada musik. Penga- laman semasa kecil tentang pekerjaan dan hobi ayahnya, yaitu perpaduan antara pengetahuan teknologi dan seni inilah yang akhirnya mendorong Soegeng Toekio memilih melanjutkan kuliah di seni rupa ITB yang diselesaikan pada tahun 1974

Soegeng Toekio hijrah ke Solo pada tahun 1979. Pada saat itu diterima sebagai pegawai ASKI (Akademi Seni Karawitan Surakarta) untuk membentuk Bengkel Kerja Seni Rupa (BKSR) sebagai cikal bakal berdirinya Institut Seni Indonesia (ISI) Surakarta. Pada tahun 1980an di BKSR tersebut, Soegeng Toekio mengenal wayang beber dan aktif mengembangkannya melalui lukisan wayang beber di kaca.

Peran Soegeng Toekio dalam mengembangkan lukis wayang beber sangat besar. Dia adalah ketua BKSR, yang membuat perencanaan program sekaligus koordinator pelaksananya. Soegeng Toekio ma mpu mengimplementasikan visi dan misi ASKI yang lebih mengarah kepada tradisi.

Oleh karena itu program yang dijalankan pada waktu itu adalah pengembangan seni rupa tradisi, ya -itu sebagai laboratorium penciptaan keris (tosan aji), gerabah, ga- 
melan, tatah ukir dan seni lukis kaca.

Semua pegawai BKSR harus mempelajari tradisi sesuai dengan latar belakang budaya dan minat kesenian mereka. Misalnya, IGP Sugandhi, dan Aboe Bakar yang berlatar belakang seni lukis modern barat belajar lukis kaca wayang beber, atau Bagyo Suharyono yang menggeluti keris. Pada saat itu, seni lukis kaca di Solo menjadi trend. Tidak hanya pegawai BKSR saja, tetapi juga pelukis di luar BKSR membuat paguyuban pecinta lukisan kaca yang diketuai oleh Putut H Pramono (wawancara Arfial Arsad Hakim, 19 Agustus 2016).

Dikoordinasi oleh Soegeng Toekio, para pelukis Solo tersebut beberapa kali membuat pameran lukis kaca di beberapa kota, seperti pada tahun 1983-1984 di Surakarta, Salatiga, Bandung dan Jakarta. Pada saat itu, eksistensi seni lukis kaca Soegeng Toekio dan beberapa pelukis Surakarta lainnya telah diakui dalam medan sosial seni rupa (art world).

Berbeda dengan pelukis yang belajar lukis kaca lainnya (di dalam atau di luar BKSR), yang kemudian karyanya kembali kepada gaya visualnya yang lama, Soegeng Toekio tetap konsisten terus melanjut- kan dan bereksperimentasi teknik dan penggayaan visual seni lukis wayang beber sampai sekarang. Dari tahun 1980-2002, Soegeng Toekio terus mendalami dan mengeksplorasi lukis wayang beber baik di kaca maupun di kain, dari teknik, material maupun gaya visualnya.

Pada awalnya, Soegeng Toekio membuat seni lukis kaca dengan gaya wayang beber memakai ornamen dan isen, gaya visual yang terinspirasi dari wayang beber tersebut terus diolah sampai menemukan gaya visual seperti lukisannya sekarang. Peran dan konsistensi Soegeng Toekio dalam dunia seni lukis dengan sentuhan tradisi inilah yang menarik dan penting untuk diteliti.

Pengamatan terhadap eksistensi sebuah karya seni merupakan usaha dalam upaya memahami suatu karya seni, yang bisa dilakukan dengan beberapa pendekatan, salah satunya adalah melalui kritik seni. Bahari mengatakan, kritik seni menjadi penting kehadirannya dalam upaya untuk memahami esksistensi sebuah karya seni, yaitu memahami apa yang melatarbelakangi kehadiran suatu karya seni, memahami makna pesan yang disampaikan dalam karya seni, dan memahami kelebihan ser- 
ta kekurangan dari sebuah karya seni yang dihasilkan seniman. Semua hal tersebut tujuan akhirnya adalah supaya orang yang melihat karya seni memperoleh informasi dan pemahaman yang berkaitan dengan mutu karya seni, dan menumbuhkan apresiasi serta tanggap -an terhadap karya seni tersebut. (Bahari, 2003: 3)

Oleh karena itu, ketika ingin memahami eksistensi seni lukis karya Soegeng Toekio, maka penelitian ini menggunakan pendekatan kritik seni holistik. Penggunaan kritik seni holistik ini diharapkan nantinya akan diketahui, (1) latar belakang kelahiran seni lukis karya Soegeng Toekio, (2) estetika formal seni lukis karya Soegeng Toekio, dan (3) tanggapan penghayat setelah melakukan pengamatan secara afektif terhadap karya seni lukis Soegeng Toekio.

Penelitian ini menggunakan metode metode kualitatif dengan desain deskriptif, yaitu penelitian yang memberi gambaran secara cermat mengenai individu atau kelompok tertentu tentang keadaan dan gejala yang terjadi (Koentjaraningrat, 1993:89). Langkah pertama yang dilakukan adalah pengumpulan data dari ketiga sumber informasi yang dipersyaratkan oleh kritik seni holistik yaitu, latar belakang penciptaan karya Soegeng Toekio sebagai informasi genetik, karya seni lukis Soegeng Toekio sebagai informasi obyektif dan tanggapan para penghayat sebagai informasi afektif.

Setelah sumber data tersebut terkumpul kemudian dianalisis megunakan interaksi analisis (sumber informasi genetik dan afektif) dan analisis interpretatif untuk sumber informasi obyektif. Setelah semua data dianalisis kemudian disintesakan dan ditarik kesimpulan yang berkaitan dengan karakteristik seni lukis karya Soegeng Toekio.

\section{PEMBAHASAN}

\section{Latar Belakang Penciptaan Karya Soegeng Toekio}

Sejak kecil Soegeng Toekio hidup dalam dua budaya, di dalam keluarga dia mengenal budaya Jawa dan di luar rumah mengenal budaya Sunda.

\footnotetext{
"Nilai-nilai yang berlaku di keluargaku adalah budaya Jawa. Kalau ibu marah selalu menggunakan bahasa Jawa, tapi anak-ananya menjawab dengan bahasa Sunda". (Wawancara Soegeng Toekio, 11 Juli 2016)

Saat duduk di sekolah rakyat, antara kelas satu sampai kelas tiga, Soegeng Toekio tinggal bersama nenek dan kakeknya, R. Martotaru-
} 
no di daerah Cibunut Bandung. Dari mereka Sogeng Toekio mengenal tradisi Jawa melalui ritual perayaan dalam budaya Jawa.

"Saya dulu sering diajak mbah Marto putri rewang. Pernah ikut prosesi mitoni, lihat orang bikin gambar wayang di atas kelapa kuning/gading, atau pas midodareni lihat janur yang dibikin hiasan". (Wawancara Soegeng Toekio, 11 Juli 2016)

Selain diajak mendatangi beberapa ritual perayaan budaya Jawa, Soegeng Toekio juga sering diajak menonton pertunjukan wayang orang di gedung Sri Murni yang terletak di daerah Kosambi Bandung. Pertunjukan tersebut selalu dipadati penonton terutama komunitas masyarakat Jawa yang ada di Bandung dan sekitarnya.

"Mbah Marto selalu mengajakku melihat wayang orang di gedung Sri Murni. Setiap malam minggu dan hari libur, aku selalu diajak melihat wayang orang. Setiap melihat pertunjukan tersebut, aku lebih suka melihat simbahku yang kadang-kadang tertawa, tersenyum atau kelihatan sedih. Aku tidak mengerti maksud pertunjukan itu, jadi biasanya di tengah pertunjukkan sudah tidur. Hanya saja, yang menarik buatku pada saat itu adalah suasana peralihan adegan, layar atau geber yang menghiasi panggung dan kostum pemainnya yang indah". (Wawancara Soegeng Toekio, 11 Juli 2016).

Dari dikenalkan pada ritual perayaan dan pesta dalam budaya
Jawa seperti midodareni, mitoni selapanan, dan siraman, serta melihat wayang wong/ orang yang dia jalani setiap Sabtu dan Minggu malam selama tiga tahun terus menerus telah mengkontruksi pemikirannya tentang sebuah nilai keindahan dalam perpektif budaya Jawa. Hal tersebut mengendap dalam dirinya dan suatu ketika dia didesposisikan pada ranah kultural yang lain maka alam bawah sadarnya mengusulkan nilai-nilai budaya Jawa yang telah mejadi habitusnya.

Habitus Soegeng Toekio terbentuk sejak kecil. Bagaimana dia dikenalkan oleh neneknya pada seni dan tradisi budaya Jawa. Dimana dia dikenalkan pada prosesi ritual tradisi pada perayaan pesta pernikahan jawa, seperti midodareni, siraman dan temu temanten, atau melihat pertujukkan wayag orang.

Dari proses pembentukan habitus itu Soegeng Toekio sangat tertarik pada budaya visual dalam budaya jawa, seperti ukiran wayang pada cengkir (buah kelapa yang masih muda) kelapa gading dan ubo rampe (elemen pelengkap ritual/ upacara tradisi) seperti sesajen, hiasan pada pesta pernikahan. Sedangkan pada pentas per 
-tunjukan wayang orang, Soegeng

Toekio yang pada saat itu masih ke -cil (usia 5 - 6 tahunan), sangat tertarik pada kostum pemain dan geber atau gambar latar belakang panggungnya.

Habitus Soegeng Toekio tersebut yang akhirnya membuat alam bawahnya untuk mengusulkan selera estetik yang berkaitan dengan seni tradisi dalam budaya Jawa. Hal itu tercermin bagaimana ketika remaja tertarik belajar membuat ilustrasi dari Suyadi (Pak Raden) yang ilustrasinya banyak menceritakan tentang kehidupan pemain wayang tobong (tobong adalah istilah yang digunakan untuk menunjuk pementasan teater tradisi seper -ti wayang orang, ketoprak atau ludruk di panggung yang tidak permanen/ bongkar pasang karena tuntutan profesi yang harus berpindah-pindah tempat/ kota). Habitus Soegeng itu pulalah yang mendorongnya mengambil objek skripsinya "Tutup Kepala Tradisional Jawa" di ITB Bandung.

"Pada tahun 1970an aku melakukan penelitian untuk skripsi yang diawali dengan mengamati beberapa objek di museum $\mathrm{Pu}$ sat Jakarta, museum Radya Pustaka di Solo, museum Sono Budoyo di Yogyakarta, serta melihat acara perkawinan agung diadakan di kraton Kasunanan
Surakarta. (wawancara Soegeng Toekio, 19 Agustus 2016).

Pengalaman meneliti artefak dan mempelajari esensi makna budaya Jawa yang ada dalam artefak melalui wawancara pada tokoh seniman dan budayawan semakin menebalkan ketertarikan Soegeng Toekio terhadap budaya nusantara khususnnya Jawa.

"Ketika kucermati kosa karya perupa tradisi dengan ragam bentuk, fungsi, pemakaian bahan, sampai keunikannya; sungguh luar biasa. Aku amat terpesona olehnya, ingin mencari tahu, bahkan ada rasa iri kepada perupa generasi masa lalu yang demikian kuatnya rasa patuh mereka pada norma adati dalam mekaryanya. Ada sesuatu yang kurasakan akrab/ luluh dengannya. (Soegeng Toekio, 2015: 11)

Pengalaman penelitian yang dilakukan juga menumbuhkan kesadaran Soegeng Toekio tentang artefak budaya yang terjalinan sangat erat dengan cerita rakyat (folklore), mitos, legenda, serta sejarah. Sumber-sumber ini pula lah kemudian menjadi dasar dari setiap karya Soegeng Toekio, termasuk konsep garap wayang beber.

Memahami proses penciptaan karya Soegeng Toekio dalam penelitian ini menggunakan langkah-langkah seperti berikut: pertama, upaya menemukan gagasan, 
yaitu bagaimana upaya seniman dalam mencari sumber inspirasi yang nantinya berhubungan dengan ide atau gagasan berkaryanya; ke dua, tahap menyempurnakan, mengembangkan dan memantapkan gagasan awal, yaitu bagaimana seniman menyempurnakan, mengembangkan dan memantapkan gagasan awalnya yang dalam hal ini nanti berhubungan dengan pencarian bentuk, pilihan medium, alat, bahan dan teknik; dan ke tiga, tahap visualisasi ke dalam media, yaitu bagaimana seniman memvisuali -sasikannya ke dalam media. (L.H. Chapman dalam Sahman, 1993, 119-128).

\section{a. Pencarian sumber inspirasi}

Pencarian sumber inspirasi karya-karya Soegeng Toekio melalui observasi dan penelusuran pustaka maupun dokumen yang dapat dilakukan secara berkebalikan urutannya. Sumber inspirasi kekaryaan Soegeng Toekio yang paling utama adalah Santaka parwa atau ensiklopedi budaya sendiri.

"Santaka parwa paling tidak memuat lima komponen, yaitu mitologi, sejarah, legenda, cerita rakyat dan ritual. Itukan bahasa teks. Lah itu yang saya visualisasikannya ke dalam karyakarya saya. Kita sudah kehilangan spirit santaka parwa, itu harus digali dan dihidupkan lagi".
Inspirasi Soegeng Toekio bisa muncul kapan saja tanpa disengaja setelah melihat peristiwa tertentu di sekitarnya. Sebagai contoh karyanya yang berjudul "Pacu Dayung", muncul setelah dia melihat lomba balap perahu di Palembang yang diberitakan di televisi.

Setelah tertarik dengan peristiwa tersebut, Soegeng Toekio baru mencari referensinya. Pencarian data itu berkaitan dengan sejarahnya, dan terutama pada kostum tradisi yang digunakan oleh peserta beserta ornamen pada benda yang digunakan saat peristiwa itu berlangsung. Penelusuran itu dilaku -kan melalui pencarian di bukubuku referensi tentang budaya dimana peristiwa tersebut diselenggarakan dan penelusuran internet. Biasanya kalau penelusuran internet lebih pada pencarian gambar atau foto-foto peristiwa tersebut.

Di sisi yang lain, yang dilakukan oleh Soegeng Toekio dalam mencari inspirasi dengan melakukan observasi terlebih dahulu. Misalnya hadir dan mendokumentasikan peristiwa budaya, seperti sekaten, cembrengan, Yoqowiyu, atau ke tempat-tempat peninggalan sejarah seperti candi dan museum. Observasi yang dilakukan terebut 
bisa langsung menginspirasi dirinya bisa juga tidak dan akan menginspi -rasi di kemudian hari.

"Kalau pengamatan di lapangan itu tidak menarik minimal aku sudah mempunyai dokumentasi fotonya, yang mungkin ke depan akan berguna". (wawancara dengan Soegeng Toekio, 19 Juli 2016)

\section{b. Tahap penyempurnaan}

Tahap penyempurnaan merupakan tahap mengembangkan de -ngan memantapkan gagasan awal, yaitu bagaimana seniman menyempurnakan, mengembangkan dan memantapkan gagasan awalnya da -lam hal ini nanti berhubungan dengan pencarian bentuk, pilihan medium, alat, bahan dan teknik.

Pada tahapan ini yang dilakukan oleh Soegeng Toekio dalam proses penciptaan karyanya adalah melakukan pengembangan dan pemantapan gagasan serta pencarian bentuk terlebih pada komposisi karyanya.

Langkah pertama yang dilaku kan adalah melakukan penelusuran referensi pustaka dan dokumen. Hal ini dilakukan untuk merasakan spirit dan mengetahui makna serta esensi peristiwa budaya yang menjadi sumber inspirasinya atau makna simbol-simbol dari artefak budaya yang menjadi inspirasinya.
"Misalnya kenduren. Essensi dari kenduren sebetulnya apa sih? Material yang harus ada di dalam kenduren itu apa saja? Setelah mengetahui bahwa paling utama dalam sebuah kenduren itu adalah kehadiran nasi tumpeng maka nasi tumpeng itulah yang nantinya dijadikan point interestnya. Dan pernak-pernik yang lain kemudian dihilangkan". (wawancara Soegeng Toekio, 19 Juli 2016).

Sebagai contoh lainnya ketika melihat sebuah pertunjukkan beksan (tarian), paling penting diketaui dan dipahami adalah pola gerakan tariannya, kostum penarinya (teruta -ma aksesoris yang menonjol) dan herarki sosial yang menentukan posisi penontonnya. Hal ini penting untuk memvisualisasikan pakaian para penonton ke dalam lukisan, karena pakaian menentukan status sosial.

Dalam proses merepresentasikan ide, Soegeng Toekio tidak latah hanya selesai pada kuas dan cat, tetapi tools dan teknik tradisi yang hampir dilupakan orang dia gunakan dan dikembangkan. Seper -ti penggunaan kalam, atau biting (lidi) yang digunakan untuk menggambar ilustrasi di daun lontar digunakan untuk dalam membuat karya. Penggunaan kalam dan lidi ini yang membuat kontur dalam karya Soegeng Toekio kelihatan ha lus dan hidup. 
"Kalam ini ternyata mempunyai efek luar biasa. Sekarang yang masih menggunakan itu adalah seniman tradisi Bali. Ternyata garisnya lebih luwes, fleksibel dan dinamis. Lah, saya meminjam tools itu untuk membuat kontur dalam proses penciptaan karya saya. Kenapa karya saya selalu memakai kontur, karena teknik yang saya gunakan meminjam dari wayang beber. Tidak ada figur wayang beber yang figurnya itu dibentuk dari persinggungan warna, pasti garis. Artinya karya-karya seni tradisi itu lebih mendewakan peran garis". (wawancara dengan Soegeng Toekio, 19 Juli 2016).

Pada masa peralihan menggunakan medium kaca ke kanvas, Soegeng Toekio pernah mengguna -kan kain blacu. Pada saat itu dia sempat bereksplorasi kesan klasik pada material kain yang digunakan dalam karyanya, yaitu dengan cara dicelupakan ke dalam rebusan berbagai material.

"Untuk membentuk kesan klasik pada karya, saya mengolah kain tersebut dengan cara mencelupkan ke dalam rebusan kulit mahoni, getah pisang, papagan kayu jati dan jambu. Kalau mau awet ditambah daun suruh dikasih garam dan direbus. Prosesnya kanjinya dihilangkan dulu, kemudian dicelup dengan bahan-bahan tadi". (wawancara dengan Soegeng Toekio, 19 Juli 2016).

Penggunaan medium kain ter -sebut sudah tidak dilakukan oleh Soegeng Toekio lagi, ketika dia merasa kesulitan menggunakan warna biru seperti yang dia inginkan. Intensitas warnanya berubah karena kainnya berwarna cokelat. Akhirnya dia menggunakan kanvas. Kom posisi kekaryaan Soegeng Toekio menggunakan keseimbangan sime -tris dimana bobot kiri, kanan, atas bawahnya seimbang, karena terisnpirasi dari filosofi keseimbangan hidup masyarakat Jawa yang tertuang dalam artefak budaya, khususnya pohon hayat dan "kinnarakinnari" yang terdapat di salah satu relief candi Prambanan.

"Esensi makna dari pohon kalpataru atau pohon hayat dan kinnara-kinnari adalah keseimbangan. Kiri-kanan, atas-bawah itu adalah simetris. Sifat simetris inilah yang saya pinjam, yang tengah adalah ingsun, diri kita". (wawancara dengan Soegeng Toekio, 19 Juli 2016).

Warna yang digunakan oleh Soegeng Toekio pada karyanya sekarang adalah warna pastel, yaitu warna-warna muda yang cenderung kalem. Warna-warna ini terinspirasi oleh tren warna-warna cat tembok untuk interior dan perkembangan desain kemasan produk dari Jepang.

"Warna yang cerah terinspirasi oleh perkembangan warna cat untuk interior rumah tinggal yang kalem dan berwarna-warni dan konsep desain pembungkus produk dari Jepang, dimana desain Jepang itu, selalu bersifat temporer, kekinian dan merang- 
kul animo".(wawancara dengan Soegeng Toekio, 19 Juli 2016).

Penggunaan material kanvas sebagai bidang gambar, warna kalem dan mulai memvisualisasikan essensi sebuah peristiwa budaya dengan meninggalkan isen-isen me -rupakan usaha Soegeng Toekio untuk memodernkan karya lukisnya.

"Saya tidak ingin karya ini berhenti pada tradisi lama. Apa yang saya lakukan, seperti mengambil essensi sebuah peristiwa budaya atau nilai filosofi dalam satu legenda atau mitos dan warna yang cerah itu adalah sebuah usaha untuk menarik budaya lama ke kinian. Bahwa tradisi saya hadirkan dengan nafas kekinian. Intinya, mengkinikan tradisi". (wawancara dengan Soegeng Toekio, 19 Juli 2016).

\section{c. Tahap visualisasi karya}

Pada tahap visualisasi ke dalam karya, Soegeng Toekio melakukanya seperti halnya melukis wayang beber, yaitu menyiapkan alat dan bahan, membuat batas tepi kanvas sebagai bidang gambar kemudian membuat sket langsung ke kanvas menggunakan pensil, mewarnainya dan yang terakhir me -buat kontur untuk mempertegas figur yang dibuat.

Alat-alat yang digunakan adalah kuas ukuran 1-7 untuk mewarnai bidang gambar yang kecil dan kuas ukuran 8 untuk membuat blok latar belakangnya. Sedangkan kon -tur dibuat menggunakan kalam, lidi dan kuas nomer 1 yang diruncingkan.

Posisi kanvas disket pada posisi belum terspanram dan dibeber di atas meja seperti halnya membuat wayang beber. Hal ini dilakukan untuk memudahkan pada saat pewarnaan. Pada saat membuat sket di kanvas ini merupakan tahapan paling penting, karena dalam tahapan ini pertimbangan komposisi, besar kecilnya figur yang akan dibuat dan pemilihan letaknya dipikirkan oleh Soegeng Toekio pada tahap ini.

Eksekusi warna yang digunakan disesuaikan dengan nuansa atau kesan yang akan dibangun oleh subjek matter karyanya. Biasanya menentukan satu warna pokok kemudian yang lain menyesuaikan warna pokok tersebut dengan mempertimbangkan gradasi atau kontras.

\section{Karya Soegeng Toekio Sebagai Sumber Informasi Obyektif}

Setelah melakukan pengamat -an terhadap karya-karya Soegeng Toekio dari tahun 1985-2015, ternyata karya tersebut tidak dapat dikelompokkan berdasarkan tahun 
pembuatan, karena kecenderungan Soegeng Toekio tidak linier tetapi berubah-ubah. Kadang cara memvisualisasikan suatu karya pada tahun 1985 dapat muncul kembali pada tahun 2000an dimana dia sudah membuat karya yang "minimalis".

Dari 35 karya Soegeng Toekio dari tahun 1985-2016 yang diamati, maka penelitian ini membagi tiga bagian berdasarkan ciri visual yang hadir pada karya Soegeng Toekio. Pertama, adalah karya lukis Soegeng Toekio yang masih menggunakan isian ornamen tradisi. Kedua, karya Soegeng Toekio yang memunculkan unsur wayang kulit dalam menyimbolkan sesuatu dan ketiga adalah adalah karya-karya yang sudah mampu merepresentasikan gaya visual Soegeng Toekio. Alasannya, karena sembilan karya tersebut telah mampu mewakili kecenderungan semua karya Soegeng Toekio, yang membedakannya hanyalah pada temanya (subjek matternya).

Langkah pertama yang dilakukan adalah mengamati kesembilan karya terpilih tersebut kemudian dideskripsikan, dari bentuk, material dan teknik yang digunakan serta unsur seni lukis dan prinsip tata susunnya. Unsur seni lukis yang dimaksud adalah garis, warna, tekstur, dan bidang, sedangkan prinsip tata susun karya Soegeng Toekio kemudian dianalisis menggunakan teori estetika De Witt H.

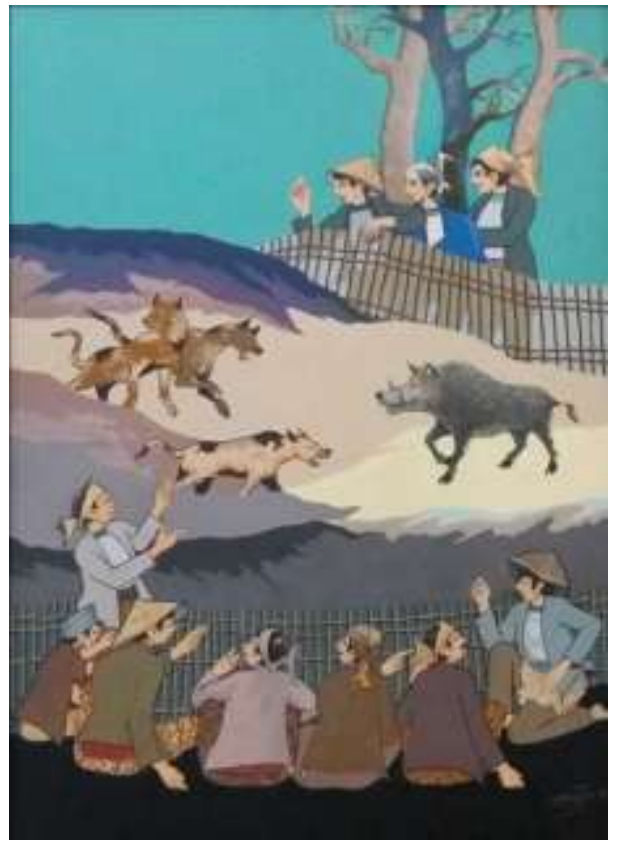

Gambar 01.

"Adu Bagong", akrilik pada kanvas $120 \mathrm{X}$ $70 \mathrm{~cm}, 2013$

Foto Isnanta, 2016

Dari hasil analisis tersebut dapat ditarik satu penilaian tentang kelemahan dan kelebihan karya Soegeng Toekio.

1. Kelebihan karya Soegeng Toekio sangat indah dan membuat hati menjadi tenteram karena dia menggunakan warna dingin. Penikmat dapat nusanta -ra melalui karya Soegeng Toe kio. 
2. Kekuranganya adalah pembagi -an bidangnya yang selalu simetris baik formal maupun informal. Komposisi warnanya yang juga monoton (analogus) membuat orang menjadi bosan dan menganggap melihat satu dua karya Soegeng Toekio sudah melihat/ menikmati seluruh karya Soegeng Toekio, karena semua sama, yang membedakan adalah subjek matternya saja.

\section{Tanggapan Pengamat Terhadap Karya Soegeng Toekio Sebagai Sumber Informasi Afektif}

Proses mengevaluasi karya seni menggunakan kritik holistik, berdasarkan pada tiga sumber informasi, yang salah satunya adalah penghayat sebagai sumber informasi afektif. Penghayat sebagai sumber informasi afektif, maksudnya adalah berupa dampak emosional pada diri penghayat. Dampak tersebut timbul setelah menghayati karya dengan beragam tafsir makna nilai akibat melakukan interaksi secara dialektis dengan karya seni di dalam proses penghayatan.

Penelitian ini memandang pehayat sebagi unsur penting dalam melihat peluang dan keberlanjutan karya seni untuk memasuki wilayah apresiasi selanjudnya yang lebih luas. Penghayat diposisikan sebagai narasumber dalam penelitian ini, pertama, adalah orang-orang yang memiliki perhatian dan mengikuti perkembangan seni rupa, yang mana mereka bisa dari kalangan kritkus seni, atau penulis di bidang seni rupa, dan ke dua adalah para expert atau ahli di bidang seni rupa, antara lain seniman dan dosen seni rupa.

Terkait dengan hal tersebut di atas, persepsi dari para penghayat dalam penelitian ini didapat dengan dengan cara wawancara dan melihat referensi dari tulisan yang sudah ada pada katalog pameran Soegeng Toekio. Tulisan-tulisan referensi yang digunakan dan dipilih terutama yang berhubungan dengan karya seni lukis Soegeng Toekio, baik yang berhubungan dengan kelahiran, bentuk maupun posisi karya seni lukis Soegeng Toekio tersebut dalam medan sosial seni rupa di Indonesia.

Pertama adalah tulisan Sri Warso Wahono dalam katalog pameran. "Solo 4 (Sekawan)" di Taman Ismail Marzuki Jakarta, 6-20 Januari 2015.

"Lukisan Soegeng Toekio berangkat dari tema yang sudah 
menjadi mitos, legenda, cerita rakyat dan religi di tengah masyarakat. Itulah mengapa kita kenali lukisan yang bersifat naratif, ada unsur dan kandungan cerita dibalik wujud visualnya. Misalnya, karya yang berdujul: "Boyong Kedaton", "Bersih Desa", "Nitibeksan", "pisowanan", dan "palagan". Kelima lukisan ini hendak menceritakan kisah atau upacara yang diikuti banyak orang pada suatu era. Figur-figur orang pelaku upacara mengguna -kan kostum tradisi jawa, dilukiskan karikatural dan berciri dekoratif-pipih. Pola pengulangan penggarapan bentuk figur yang enak dilihat pada lukisannya, mengingatkan kita pada wayang beber dimana taferil berfungsi sebagai sebuah layar dengan muatan figur kolosal. Di bagian atas, tengah atau bawah taferil, secara artistik, sadar dibuat flat. Imaji tentang ruang dan dimensional, diornamentasikan lewat perwujudan warna yang kompositoris. Karya Soegeng Toekio juga dapat dilihat jejaknya pada kekuatan seni tradisi wayang beber. Pada konteks ini, Soegeng Toekio tidaklah otonom di dalam menggeluti keseniannya, melainkan ada senyampang pengaruh yang ikut menjadi referensi esensi estetik dan artistik karya-karyanya".

Karakter lukisan karya Soegeng Toekio sangat erat kaitannya dengan wayang beber juga dijelaskan oleh Ardus M Sawega dalam pengantar pameran "Catur Gatra" di balai Soejadmoko, 1-5 Desember 2012.

"Soegeng Toekio memilih corak seni rupa bergaya tradisi, yang berangkat dari nilai-nilai estetika budaya lama seperti yang kita temukan dalam wayang beber, dengan tema folklor, legenda, mitos dan sebagainya".

Hal ini juga ditangkap oleh Kusmadi yang melihat karya Soegeng Toekio itu mempunyai sumber inspirasi dari tradisi.

"Ide-idenya bagus, konsisten berkarya dan sangat kreatif. Karyanya banyak sekali karena sangat produktif. Karyanya sangat kreatif dengan mengambil sumbernya dari Tradisi. Meskipun dia mempunyai latar belakang desain produk tetapi dia mau belajar dan mengembangkan tradisi. Terutama karya lukis kaca wayang beber. Karyanya dari dulu sampai sekarang tidak berubah, dari goresannya dan temanya juga sama. Tidak ada perubahan yang ekstrim. Penggambarannya kan tidak leterluks seperti klasik sudah dengan gayanya sendiri. Warnanya diambil dari warna-warna tradisi seperti batik, wayang yang cenderung gelap. Kalau warna memang ada perubahan, seperti warna yang lebih segar lebih kontemporer, seperti lebih bebas mengekspresikan kehendaknya. Untuk garis kelihatannya pak Soegeng terpengaruh oleh background-nya yang dari desain produk, mereka cenderung memunculkan kekhassan produknya, ada unsur-unsur kepastian atau ke-perfec-kan beda dengan orang seni murni yang lebih bebas. Keseimbangan karya pak Soegeng adalah simetris non formal dengan menyeimbangkan volume biar orang melihat itu tidak berat di satu sisi". (Wawancara dengan Kusmadi, 4 September 2016)

Dari ketiga narasumber di atas, menyebutkan bahwa corak lukisan Soegeng Toekio bergaya tra- 
disi yang dihubungkan dengan wayang beber. Padahal, pada tahun 1800an ilustrasi dalam serat-serat budaya Jawa sudah mempunyai ciri seperti bentuk figur dalam karya Soegeng Toekio, yaitu serat Selarasa (1804) dan serat Sindujoyo (1850). Serat Selarasa teknik peng -gambarannya seperti seni lukis tradisi karya Citra Waluyo, sedangkan serat Sindujoyo menyerupai wayang beber tetapi lebih sederhana.

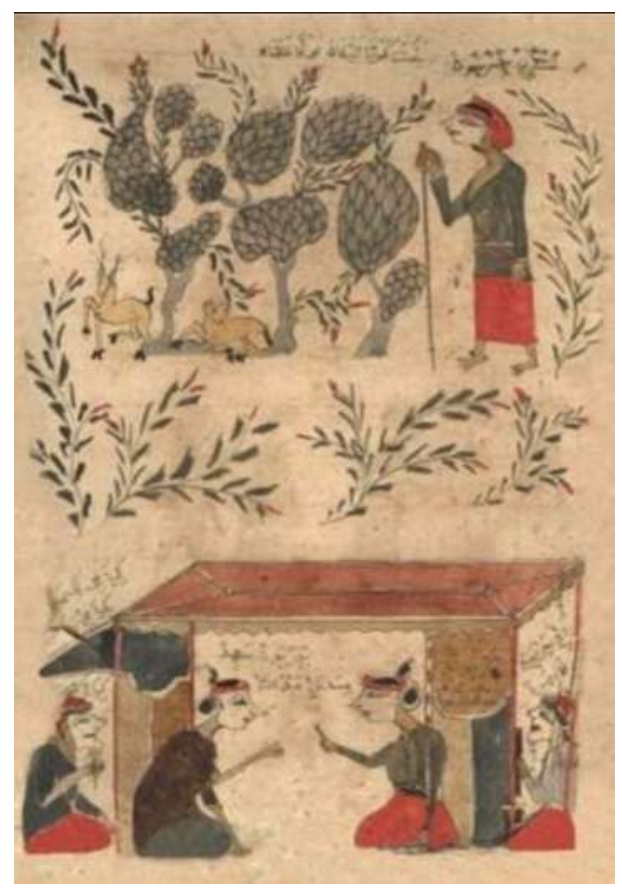

Gambar 02.

Ilustrasi naskah kuno yang lebih mirip dengan bentuk figur manusia karya Soegeng Toekio. serat Sindujoyo (kanan). Sumber: http://www.wacana.co/ 2009/05/ragam-dan-unsur-spiritualitaspada-ilustrasi-naskah-nusantara-18001900-an/

Diunduh oleh Isnanta, 10 Agustus 2016

Sedangkan Arfial Arsad Hakim lebih membahas tentang gaya lukisan karya Soegeng Toekio sebagai lukisan dekoratif ilustratif. Ga ya lukisan Soegeng Toekio adalah dekoratif-ilustratif. Hal ini dilihat dari kesan pertama ketika melihat karya Soegeng Toekio.

"Karya Soegeng Toekio itu dekoratif ilustratif. Dekoratif berkaitan dengan bagaimana usaha dia memperindah karyanya, baik dengan ornamen atau komposisi warnanya. Jejak ilustrasinya sangat kuat terlihat dari bagaimana dia menstilasi figur orang, binatang atau benda dalam karyanya. Terutama figur orangnya, mungkin karena latar belakang dia yang lama menjadi seorang ilustrator." (Wawancara dengan Arfial Arsad Hakim, 19 Juli 2016)

Ada benarnya ketika Arfial Arsad Hakim mengatakan bahwa cara penggambara figur manusia dan objek lain dalam karya Soegeng Toekio menggunakan teknik barat, karena adanya artefak ilustrasi naskah Jawa yang terpengaruh teknik barat setelah Belanda masuk ke Indonesia, yaitu serat Damar Wulan (1815).

Pada karya Soegeng Toekio, kostum atau pakaian menjadi elemen yang sangat penting. Pakaian tidaklah benda yang bebas nilai, karena merepresentasikan sesuatu. Misalnya baju dan celana tani hitam dengan kaos putih bergaris merah akan merepresentasikan warok atau Ponorogo. Demikian halnya 
dengan blangkon atau penitip kepala lainnya. Dengan tenik penggambaran figur yang sama, maka kostum menjadi salah satu penanda orang yang di dalam karya tersebut berasal. Hal ini juga ditangkap oleh Arfial Arsad Hakim.

"Penggambaran figur manusia dalam karya Soegeng Toekio itu hampir semuanya sama yang membedakan ada -lah pakaiannya. Kalau pakaian itu dilepas dari figurnya kita tidak dapat mengetahui orang tersebut berasal dari mana. Karena kostum atau pakaian itu yang menghidupkan dan menumbuhkan ke-san tradisi pada karyanya". (wawan cara dengan Arfial Arsad Hakim, 19 Juli 2016).
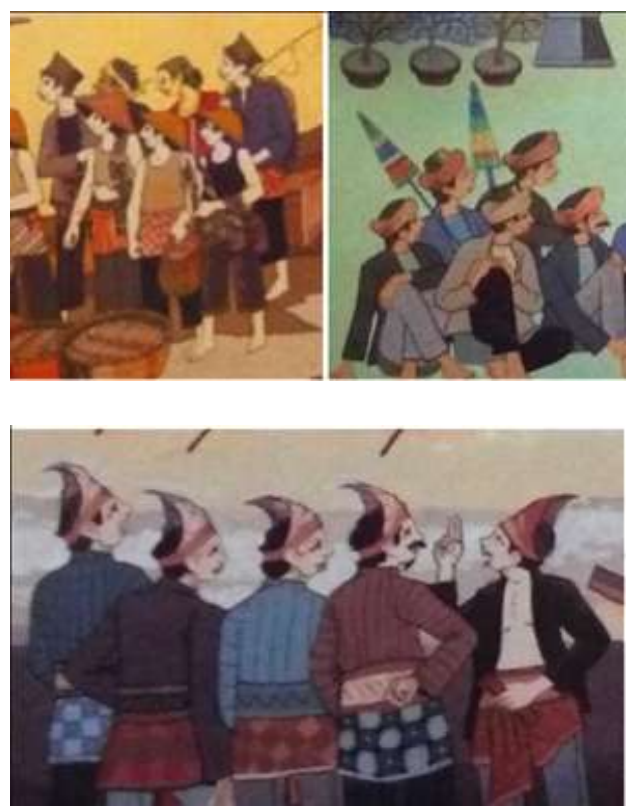

Gambar 03.

Cara penggambaran bentuk Figur manusia yang sama dengan berbagai posisi dan aktivitas yang hanya dibedakan dari pakaian yang dikenakan.

(Foto Isnanta, 2016)
Karya Soegeng Toekio bergaya dekoratif juga ditangkap oleh $\mathrm{Pu}$ tut H Pramono (66):

"Karya Soegeng Toekio itu dekoratif ilustratif. Menceritakan peristiwa yang ada di sekitarnya. Kekuatan karyanya terlihat dari figur-figur orangnya. Kadangkadang karyanya satir yang mungkin hasil dari luapan emosinya yang terpendam karena selama ini jiwanya merasa tertekan. Contohnya seperti karya yang ini, Nitibeksan, Tiba-tiba ada salah satu penari yang posisinya aneh, seolah menyindir orang yang sedang duduk di kursi. Pada karya ini dia menerangkan ke teman-temannya kalau yang duduk di kursi ini si $\mathrm{A}$ atau si B (merujuk pada jajaran pimpinan STSI), Jadi humor yang berisi sindiran, ya satir tadi". (Wawancara, 15 Juni 2016)

\section{Satu kenakalan Soegeng Toe} kio lain yang ditemukan pada karyanya yang berjudul "Bersih Desa". Pada karya tersebut menggambarkan prosesi sedekah bumi setelah panen raya. Banyak orang berkumpul di tanah lapang, terlihat beberapa perempuan yang datang beriringan dengan membawa makanan di atas kepalanya. Kalau diperhatikan lebih dekat, dari iringan beberapa perempuan itu cantikcantik, tiba-tiba muncul perempuan dengan gigi yang tonggos sangat besar dan di belakangnya seorang perempuan dengan rahang dan mulut seperti monyet. 

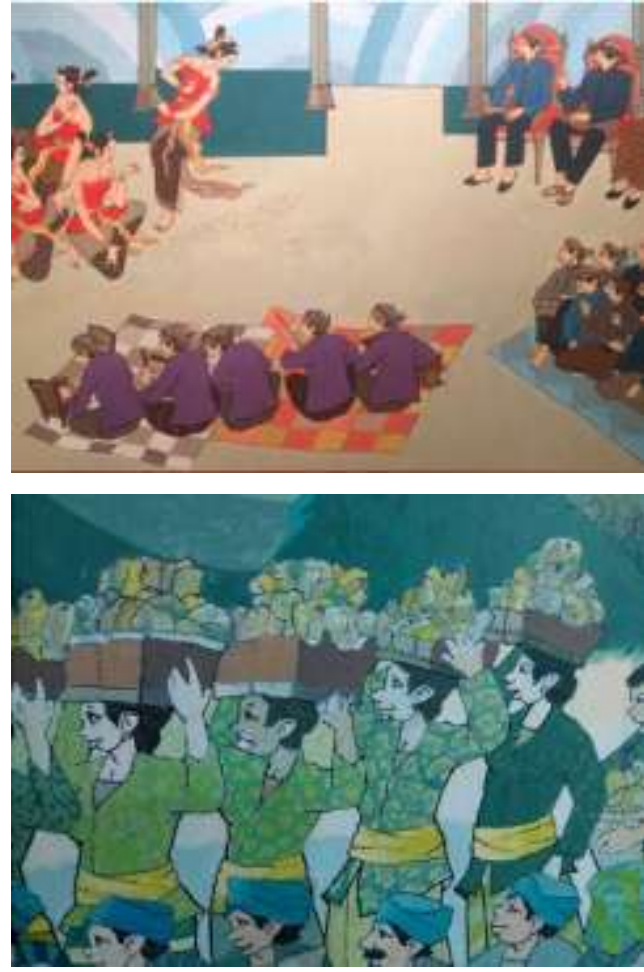

Gambar 04.

Lukisan Soegeng Toekio berjudul Nitibeksan (kiri) dan "Bersih Desa", yang mengandung sindiran yang satir. (Foto Isnanta, 2016)

Tanggapan Subandi lebih me -nekankan pada konsep berkesenian dan konsep seninya. Dia melihat karya Soegeng Toekio itu merupakan perkawinan anatara modern dan tradisi.

"Apa yang ditawarkan pak Soegeng adalah sebuah perkawinan idealisme dengan konsep berkarya modern dengan mengambil tradisi sebagai subjek matter yang digarap kekinian. Keberhasilan karya pak Soegeng bukan bentuknya yang indah kemudian memikat banyak orang tetapi sebuah eksperimentasi konsep modern yang mengambil subjek matter tradisi. Dia konsisten karena karyanya dari dulu sampai sekarang tidak berubah, kalau persoalan warna, mungkin dia hanya ingin mencari kesegaran warna yang menurut saya hanya temporary," (Wawancara dengan Subandi, 4 September 2016)

Tanggapan Bonyong Munni Ardhi (66) terhadap karya Soegeng Toekio seperti halnya Subandi yang lebih menekankan pada konsep seni, "fine art"-nya. Bonyong melihat karya Soegeg Toekio yang bergaya dekoratif dengan menampilkan unsur tradisi untuk kepenting -an keindahan karyanya (mengindah-indahkan), bukan untuk kebutuhan ekspresi individunya.

"Karya Soegeng Toekio itu dekoratif tradisional. Polais dan menghias. Dia sangat suka mehias karyanya dengan isian-isian ornamen tradisi. Bahkan sampai ke piguranya juga dihias, ditatah dengan ornamen. Tidak ada ekspresinya. Beda misalnya dengan Nyoman Gunarso atau Sri Hadi Soedarsono misalnya. Dia menggambar penari tetapi ekspresinya terasa. Apa yang dimunculkan dalam karyanya itu semata-mata demi ekspresinya bukan menghias". (wawancara dengan Bonyong Munni Ardhi, 5 Agustus 2016)

Berbeda dengan tanggapan narasumber lainnya, pendapat Narsen Affatara (66) tentang karya Soe geng Toekio yang tidak dilihat se cara formal, tetapi diletakkan pada medan sosial seni rupanya.

"Karya pak Soegeng Toekio itu adalah karya dekoratif komersial. Karya dekoratif yang bernuansa tradisi. Tradisi yang dimunculkan memang hanya untuk dijual, 
yang dulu sudah lama dirintis oleh pelukis-pelukis Ancol atau Sukawati. Aspek genetiknya mungkin karena dia dulu adalah lulusan desain produk, sehingga dia memperlakukan karyanya seperti barang atau produk lainnya. Tetapi dia lupa bahwa karya-karya yang seperti itu sudah lama dilakukan di Ancol". (wawancara dengan Narsen Affatara, 3 Agustus 2016)

Sebuah karya seni merupakan produk dari proses sosial, oleh karena itu dalam memahami karya seni tidak hanya sebatas pada medan kajian estetika (formal), tetapi juga mencakup medan kajian seni yang lain, yaitu medan sosial seni (art world). Medan kajian seni rupa ini mengaitkan hubungan antara berbagai pihak-pihak yang ada dalam rangkaian besar seni rupa. Hal ini cukup penting dikaji sebab bagaimanapun juga karya seni dan senimannya tidak dapat berdiri sendiri. Apalagi bila karya seni tersebut dipamerkan, ia tak bisa lepas dari nilai-nilai yang lain. Secara singkat pengertian art world adalah semacam jaringan organisasi sosial yang mendukung dan berpartisipasi dalam "produksi, distribusi dan konsumsi. (Asmudjo J. Irianto, 2000: 88).

Setiap karya seni mempunyai medan sosial seni sendiri-sendiri dan mempunyai aparatus penyang- ganya sendiri. Persoalannya akan muncul ketika sebuah medan sosial seni rupa tertentu akan bersinggungan dengan medan sosial seni rupa lainnya. Perbedaan persepsi atau anggapan tentang sebuah produk itu dianggap sebagai karya seni bernilai tinggi atau tidak sangat ditentukan oleh selera estetik (seni) para pelaku yang ada di medan sosial seni tersebut.

\section{SIMPULAN}

Setelah menyelesaikan seluruh proses kajian karakteristik seni lukis Soegeng Toekio dengan pendekatan Kritik Holistik, yaitu pengumpulan data, menganalisis data dan mensitesa data dari ketiga sumber informasi, yaitu sumber informasi genetik, obyektif, dan afektif maka tahap selanjutnya adalah menyimpulkan hasil penelitian ini.

Pertama karakter seni lukis karya Soegeng Toekio terbentuk dari habitus Soegeng Toekio yang dibentuk ketika dia kelas satu di Sekolah Rakyat, pada saat tinggal bersama neneknya yang memaksanya melihat pertunjukkan wayang wong di gedung Sri Murni di daerah Kesambi Bandung. Dari sana dia mengenal seni budaya Jawa khususnya wayang wong. Hal yang me lekat dalam alam bawah sadarnya 
adalah kostum wayang wong tersebut dan geber/ ornamen pada layar panggung wayang wong.

Habitus tersebut mengusulkan Sogeng Toekio untuk belajar ilustrasi pada Suyadi (pak Raden) yang mempunyai kesamaan selera estetik yang berkaitan dengan tradisi budaya Jawa. Selanjutnya skill membuat ilustrasi Sogeng Toekio terus ditempa ketika menjadi ilustrator. Habitus tersebut yang akhirnya mengusulkan gaya visual seni lukis Soegeng Toekio sekarang.

Kedua, faktor obyektif. Kelemahan dan kekurangan karya Soegeng Toekio sebagai berikut:

Kelebihan karya Soegeng Toekio sangat indah dan membuat hati menjadi tenteram karena dia menggunakan warna dingin. Penikmat dapat mengenal budaya tradisi Jawa/ nusantara melalui karya Soegeng Toekio.

Kekurang karyanya adalah pembagian bidangnya yang selalu simetris baik formal maupun informal. Komposisi warnanya yang juga monoton (analogus) membuat orang menjadi bosan dan menganggap melihat satu dua karya Soegeng Toekio sudah melihat/ menikmati seluruh karya Soegeng Tokio, karena semua sama, yang membedakan adalah subjek matternya saja.

Ketiga faktor Afektif karya Soegeng Toekio dikenal bergaya dekoratif figuratif ilustratif. Figuratif berkaitan dengan karakter figurnya yang dipengaruhi oleh skillnya mem -buat ilustrasi dan ilustratif karena menceritakan sebuah peristiwa budaya yang ada di sekitarnya. Karya Sogeng Toekio dipengaruhi oleh latar belakangnya sebagai ilustrator dan desainer produk. Karya Soegeng Toekio jenikal satir.

Dari hasil sintesa analisis ke tiga aspek sumber informasi tersebut akhirnya menghasilkan sebuah kesimpulan bahwa karakter karya Soegeng Toekio bergaya dekoratif figuratif ilustratif, yaitu karya seni lukis dengan gaya dekoratif yang menggunakan cara penggambaran yang diindah-indahkan (stilasi), dengan kekuatan pada figur yang khas komikal dengan bentuk seperti wayang beber. Meng -ilustrasikan peristiwa tradisi yang diidentifikasi dari pakaian figur manusianya yang kemudian dikontraskan/ dipertetntangkan dengan warna-warna populer kekinian. 


\section{DAFTAR PUSTAKA}

Bahari, Nooryan. Kritik Seni, Wacana Apresiasi dan Kreasi, Penerbit Pustaka pelajar Yogyakarta, 2008.

Binawan, Al. Andang L. "Habitus (?) Nyampah: Sebuah Refleksi," dalam Basis, Nomor 05-06, Tahun ke 56, Mei-Juni 2007.

Bourdieu, Pierre, Distinction: A Social Critique of The Judgement of Taste. New York: Routledge and Kegan Paul Ltd, 1984.

,Language and Symbolic Power, terj. dari bahasa Prancis oleh Gino Raymond \& Matthew Adamson, (Cambridge: Polity Press), cet. 4, 1995.

Bourdieu, Pierre and Loic J. D. Waquant, An Invitation to Reflexive Sociology, Chicago, The University if Chicago Press Ltd, 1992.

Burke, Peter, Sejarah dan Teori Sosial, Jakarta: Yayasan Obor, 2001. Hal. 179-180.

Chapman, Laura H. Approaches to Art in Education. New york: Harcourt Brace Jovanovic, Inc. 1978. hlm. 44-62.

Choidir, M, "Kajian Visual Gambar Beber Karya Soegeng Toekio Tahun 2011-2012", dalam Jurnal Brikolase Vol. 5 No. 2 Desember 2013. hal. 89-100.

Dharsono, Kritik Seni, Bandung, Rekayasa Sains, 2007.
Seni Lukis Wayang, Surakarta, ISI Press, 2012.

Gie, The Liang. Filsafat Keindahan; Yogyakarta: Pusat Belajar IImu Berguna (PUBIB), 1996.

Goetz, J.P dan Le Comte, MD, Ethnography and Qualitative Design in Educational Research. New York: Academic Press, Inc, 1984.

Jenkins, Richard, Membaca Pikiran Pierre Bourdieu (Terj: Nurhadi), Yogyakarta: Kreasi Wacana, 2004.

Kleden, Ignas. "Habitus: Iman dalam Perspektif Cultural Production" dalam RP An drianus Sunarko, OFM, dkk. (eds.) Bangkit dan Ber geraklah: Dokumentasi Hasil Sidang Agung Gereja Katolik Indonesia 2005, Jakarta: Sekretariat SAGKI, 2005.

Koentjaraningrat, Metode-metode Penelitian Masyarakat. Jakarta, Gramedia Pustaka Utama, 1993.

Mahar, Chleen dan Richard Bar ker. (Habitus $X$ Modal) + Ranah = Praktik: Pengantar Paling Komprehensif kepada Pemikiran Pierre Bourdieu, Jogjakarta, Jalasutra, 2010.

Maleong, Lexy A. 1998, Metode Penelitian Kualitatif, Bandung : P.T. Gramedia.

Ritzer, George, and Doouglas Goodman, Teori Sosiologi Modern (Terj: Nurhadi) , Jakarta, Kencana, 2003.

Teori Sosiologi: Dari Teori Sosiologi Klasik Sampai Perkembangan Mutakhir 
Teori Sosial Postmodern (Terj: $\quad$ Nurhadi)Yogyakarta: Kreasi Wacana, 2010. Teori Sosiologi Klasik - Post Modern Edisi Terbaru (Terj: Nurhadi). Yogyakarta: Kreasi Wacana. 2012.

Sahman, Humar, Mengenali Dunia Seni Rupa, Tentang Seni, Karya Seni, Aktivitas Kreatif, Apresiasi, Kritik dan Estetika, IKIP Semarang Press. 1993.

Sugiyono, Metode Penelitian Kualitatif .Bandung: Alfabeta, 2009.

Memahami Penelitian Kualitatif, Bandung: Alfabeta, 2012.

Sahman, Humar. Mengenali Dunia Seni Rupa, Tentang Seni, Karya Seni, Aktivitas Kreatif, Apresiasi, Kritik dan Estetika, Semarang: IKIP Semarang Press, 1993. hlm119-128.

Sawega, Ardus M, "Empat Guru Menguak Takdir", dalam katalog pameran "Catur Gatra" di Balai Soedjatmoko Surakarta, 1-5 Desember 2012.

Sulistyo-Basuki. Metode Pene litian. Jakarta: Wedatama Widya Sastra dan Fakultas IImu Pengetahuan Budaya Universitas Indonesia, 2006.

Sumardjo, Jakob, Filsafat Seni, Bandung, Penerbit ITB, 2000.

Vicharius DJ, "Kolaborasi Empat Perupa Solo di Satu Panggung, dalam http:// satulingkar.com/detail/read/8/ 2790/kolaborasi-empat-pe rupa-solo-di-satu-panggung, 2015. diunduh 21 Juni 2016.

Wahono, Sri Warso, "Seni Lukis di Solo dan 4 Sekawan 2015", dalam katalog pameran, "Solo 4 (Sekawan)" di Taman Ismail Marzuki Jakarta, 6-20 Januari 2015

Zamroni. Pengantar Pengembang an Teori Sosial. Yogyakarta: Tiara Wacana,1992.

\section{DAFTAR NARASUMBER}

Afatara, Narsen. (66). Guru Besar Seni Rupa FSRD UND. JI. Ir. Sutami No. 17a Kentingan Surakarta.

Ardhi, Bonyong Munni. (70) Perupa. Jl. Rajawali No. 14 Perum. Dosen UNS IV Triyagan Mojolaban Sukoharjo.

Hakim, Arfial Arsad (66), Pelukis. Perum. Maduasri Blok A No. 3 Gawanan Colomadu Karanganyar.

Kusmadi (61), Dosen Kriya FSRD ISI Surakarta. JI, Ki Hajar Dewantoro No. 19 Kentingan Surakarta

Madi, Imam (65), Dosen Kriya FSRD ISI Surakarta. JI, Ki Hajar Dewantoro No. 19 Kentingan Surakarta

Pramono, Putut H (60), Pelukis dan dosen DKV FSRD UNS. JI. Tunggul Kawung No. 6 Perum RC Palur Karanganyar.

Subandi (58), Dosen Kriya FSRD ISI Surakarta. JI, Ki Hajar Dewantoro No. 19 Kentingan Surakarta 
Suryodarmo, Suprapto (71), Seniman dan pemilik Padepokan Lemah Putih. Desa Bonorejo RT 01 RW 02, kel. Plesungan Gondangrejo, Karanganyar.

Toekio, Soegeng (74), Pelukis dan Dekan Fakultas Seni Rupa USAHID Surakarta. Perum. Maduasri Blok A No. 34 Gawanan Colomadu Karanganyar. 